\title{
ANALISIS MOTIVASI BELAJAR SISWA SD ALBAROKAH 448 BANDUNG DENGAN MENGGUNAKAN MEDIA ICT BERBASIS FOR VBA EXCEL PADA MATERI GARIS BILANGAN
}

\author{
Siti Romlah ${ }^{1}$,Nurlela Nugraha ${ }^{2}$, Siti Nurjanah ${ }^{3}$, Wahyu Setiawan $^{4}$ \\ ${ }_{1,2,3,4}$ IKIP Siliwangi, Jl. Terusan Jendral Sudirman Cimahi 40526 \\ lisnasitiromlah@gmail.com
}

\begin{abstract}
The purpose of this study was to describe the learning motivation of Albarokah 448 Elementary School students using ICT based media for excel VBA on the number line material. The research method used is descriptive qualitative method. The research subjects were conducted on 35 students of Albarokah Elementary School 448 Bandung class VI. The instruments provided were questionnaires on the student learning motivation scale consisting of 20 statements and 4 answer choices, namely 1. Strongly Agree (SS), 2. Agree (S), 3. Disagree (TS), 4. Very Disagree (STS. The learning motivation questionnaire related to ICT-based VBA excel media consists of 4 indicators. The results of the study show that the learning motivation of students at Albarokah Elementary School 448 Bandung using ICT-based media for VBA excel on the number line material as a whole is very good and there are 3 indicators that enter the criteria are very good, for indicators of confidence in using mathematics (very good), flexible indicators in doing mathematical work (very good), voluntary indicators leaving other obligations or tasks, (very good). In working on mathematics (good), and can be seen the average overall percentage of all students included in the very criteria well.
\end{abstract}

Keywords: Mathematics Learning Motivation, ICT based on Excel VBA, Outline.

\begin{abstract}
Abstrak
Tujuan penelitian ini adalah untuk mendeskripsikan motivasi belajar siswa SD Albarokah 448 Bandung dengan menggunakan media ICT berbasis for VBA excel pada materi garis bilangan. Metode penelitian yang digunakan adalah metode kualitatif deskriptif. Subjek penelitian yang dilakukan yaitu pada 35 siswa SD Albarokah 448 Bandung kelasVI. Instrumen yang diberikan berupa angket skala motivasi belajar siswa yang terdiri dari 20 pernyataan dan 4 pilihan jawaban yaitu 1. Sangat Setuju (SS), 2.Setuju (S), 3.Tidak Setuju (TS), 4. Sangat Tidak Setuju (STS). Angket motivasi belajar yang berhubungan dengan media ICT berbasis VBA excel terdiri dari 4 indikator. Hasil penelitian menunjukan bahwa motivasi belajar siswa SD Albarokah 448 Bandung dengan menggunakan media ICT berbasis for VBA excel pada materi garis bilangan secara keseluruhan tergolong sangat baik dan terdapat 3 indikator yang masuk kriteria baik sekali yaitu untuk indikator Percaya diri dalam menggunakan matematika (sangat baik), indikator Flekibel dalam melakukan kerja matematika (sangat baik); indikator Kerelaan meninggalkan kewajiban atau tugas lain, (sangat baik ). Terdapat 1 indikator yang masuk kriteria baik yaitu indikator Ketekunan dalam mengerjakan matematika (baik). Dan dapatdilihatrataratapersentasekeseluruhan semuasiswa termasuk kedalamkriteriasangatbaik.
\end{abstract}

Kata Kunci:MotivasiBelajarMatematika,ICTberbasis VBA Excel,GarisBIlangan.

Matematika merupakan pelajaran dasar yang harus dikuasai siswa dimana pelajaran tersebut berkaitan langsung dengan kehidupan sehari-hari baik dalam jual beli, perniagaan, jam, alat transaksi dan lainnya. Selain itu matematika merupakan ilmu yang mendukung dan berperan aktifdalam perkembangan Ilmu Pengetahuan Teknologi (IPTEK). Dengan demikian matematika sangat penting untuk dipelajari oleh siswa. Dengan belajar matematika setidaknya ilmu dasar yang menopang ilmu lainnya sudah dikuasai oleh siswa sehingga pada proses pembelajaran dapat berjalan dengan baik. Belajar matematika merupakan suatu proses pembelajaran matematikayang dapatmelatih berpikir siswa agar mampu berpikirsecara logis,kritisdankreatif(Nugraha, Kadarisma, \& Setiawan, 2018) 
Seorang guru harus bisa menciptakan suatu kondisi atau proses yang mampu mengarahkan siswanya untuk melakukan aktivitas belajar. Karena dalam hal ini seorang guru mempunyai peran yang sangat penting mengingat tugas seorang guru sebagai motivator. Jadi seorang guru harus bisa menumbuhkan dan memberikan motivasi kepada siswanya. Mc. Donald (Sardiman:2007) mengatakan bahwa "motivasi adalah perubahan energi dalam diri seseorang yang di tandai dengan munculnya "feeling" dan di dahului dengan tanggapan terhadap adanya tujuan". Pembelajara matematika memiliki fungsi sebagai sarana untuk mengembangkan kemampuan komunikasi berpikir kritis, logis, kreatif, dan bekerjasama yang diperlukan siswa dalam kehidupan yang semakin maju ini. Mata pelajaran matematika telah tercantum dalam standar isi satuan pendidikan dasar diberikan kepada semua peserta didik dari sekolah dasar untuk membekali peserta didik dengan kemampuan berpikir logis, komunikatif, analitis, sistematis, kritis, dan kreatif serta bekerjasama(Romlah, Kadarisma, \& Setiawan, 2018)

Untuk belajar dengan baik maka di perlukan motivasi yang baik pula. Siswa yang mengikuti pelajaran tanpa adanya motivasi maka tidak akan mendapatkan hasil yang baik dari proses belajar mengajar tersebut. Berdasarkan hasil penelitian yang dilakukan oleh (Pebriana 2017). Motivasi belajar matematika siswa masih tergolong rendah sehingga mengakibatkan hasil belajar yang rendah pula. Hasil ini dapat dilihat dari banyaknya siswa yang belum mencapai Kriteria Ketuntasan Minimal (KKM) yang ditetapkan sekolah yaitu 69. Dari jumlah siswa sebanyak 25 siswa hanya 12 siswa yang mencapai KKM. Sedangkan 13 siswa yang lainnya belum mencapai KKM. 12 siswa dari 25 siswa yang mencapai KKM hanya $48 \%$ yang dikatakan tuntas, sedangkan ketuntasan klasikal adalah $85 \%$ dari seluruh siswa.

Penggunaan media dalam proses belajar merupakan salah satu cara yang dapat digunakan untuk membangkitkan motivasi belajar siswa. Menurut Bernard (2018) Media pembelajaran dalam matematika adalah alat untuk menggambarkan siswa bahwa mereka dapat memahami bagaimana menerapkan ke berbagai bentuk masalah yang berkaitan dengan matematika. Media juga merupakan salah hal mutlak yang ada dalam proses belajar, salah satu penerapan media dalam opembelajaran yaitu dengan menggunakan ICT berbasis VBA Excel . Gerlach dan Ely (Hamdani: 2011) mengatakan bahwa "media apabila dipahami secara garis besar adalah manusia, materi, atau kejadian yang membangun kondisi yang membuat siswa mampu memperoleh pengetahuan, keterampilan, atau sikap". Media yang menarik akan mempengaruhi motivasi belajar, ketika siswa menilai bahwa apa yang di tampilkan oleh guru itu menarik maka ia akan terdorong atau merasa tertantang untuk mengetahui apa yang akan di sampaikan oleh guru sehingga proses belajar akan menjadi lebih menyenangkan. Tetapi sebaliknya jika siswa menilai apa yang di tampilkan guru tidak menarik maka siswa akan datar saja dalam mengikuti proses belajar.

Media pembelajaran yang digunakan oleh peneliti adalah ICT For VBA Berbasis Microsoft Excel. Microsoft Excel dipilih karena perangkat lunaknya kaya akan fungsi matematika. Di Microsoft Excel, penggunaan sebagai pemrosesan numerik mengembangkan manfaatnya di bidang tertentu 
seperti statistik, keuangan, teknik dan logika matematika. Perintah dalam Microsoft Excel berhubungan dengan matematika sehingga memudahkan pekerjaan yang termasuk dalam pendidikan matematika. Microsoft Excel adalah perangkat lunak yang menyediakan gambar dengan berbagai ukuran dan bentuk sehingga dapat merancang sesuai dengan kebutuhan alat peraga bahan. Di Microsoft, gambar Excel dapat dipesan untuk dipindahkan untuk membuat game lebih menarik terlebih untuk anak SD pada materi garis bilangan yang terkadang mengecoh siswa dan menghambat pemahaman siswa. Perintah untuk membuat objek atau gambar dalam Microsoft Excel menjadi interaktif adalah menulis turun Aplikasi Visual Basic untuk kode Microsoft Excel begitu itu bisa menjalankan program dan hasil dari objek atau gambar itu statis menjadi dinamis. Jadi Microsoft Excel dapat menjadi perangkat lunak alat belajar matematika.

Berdasarkan latar belakang diatas, peneliti akan melakukan studi pendahuluan dengan judul "Annalisis Motivasi Belajar Siswa SD AlBarokah 448 Bandung Dengan Menggunakan Media ICT Berbasis For VBA Excel Pada Materi Garis Bilangan”. Salah satu materi yang termuat dalam kurikulum Matematika SD adalah materiGaris Bilangan. Peneliti memandang materi ini sangat penting karena materi Garis Bilangan merupakan materi esensial. Materi bentuk Garis Bilangan menyajikan cara operasi bilangan bulat positif dan negative yang siswa banyak mrengalami kekeliruan . Indikator motivasi belajar matematik berbantuan ICT for VBA Excel yang pakai dalam penelitian ini percaya diri dalam menggunakan matematika, flekibel dalam melakukan kerja matematika, kerelaan meninggalkan kewajiban atau tugas lain, ketekunan dalam mengerjakan matematika.

\section{METODE DAN DESAIN PENELITIAN}

Jenis penelitian ini adalah penelitian kualitatif desktritif. Penelitian ini bertujuan untuk menganalisis motivasi belajar siswa SD dengan menggunakan ICT berbasis VBA Excel pada materi Garis Bilangan yang berpedoman pada terpenuhi atau tidaknya indikator-indikator motivasi belajar. Adapun subjek penelitian ini yaitu 35 siswa SD kelas VI di Bandung. Waktu penelitian dilakukan pada akhir semester ganjil tahun ajaran 2018-2019. Pengumpulan data dalam penelitian menggunakan instrumen angket skala motivasi belajar. Instrumen digunakan sebagai upaya untuk memperoleh data primer dalam motivasi belajar siswa SD kelas VI. Adapun cangkupan materi yang disampaikan peneliti sebelum siswa memberikan respon instrument angket peneliti menerangkan materi garis bilangan menggunakan media ICT berbasis VBA Excel. Instrumen yang di gunakan dalam penelitian adalah angket skala motivasi belajar yang terdiridari 20 pernyataan dan 4 indikator yang berhubungan dengan media ICT berbasis VBA Excel dan 4 pilihan jawaban.Pemberian skor hasil tes siswa di dasarkan pada indikator yang akan dicapai. Selanjutnya skor per indikator dan skor keseluruhan siswa dikonversi dalambentuk nilai skala(1-100) serta menafsirkan data sesuai kriteria pemahaman berdasarkan Arikunto (2008). Data dikatagorikan dengan menggunakan batasanyang ditemukanolehArikunto (2008), batasan tersebut tercantum pada Tabel1 berikut ini: 
Tabel 1.

Kriteria Data

\begin{tabular}{|l|l|}
\hline Persentase & Kriteria \\
\hline $81-100$ & Baik sekali \\
\hline $61-80$ & Baik \\
\hline $41-60$ & Cukup \\
\hline $21-40$ & Kurang \\
\hline $0-20$ & Kurang Sekali \\
\hline
\end{tabular}

\section{HASIL DAN PEMBAHASAN}

Angket motivasi belajar yang terdiri dari 6 indikator beserta 20 skala pernyataan. Angket tersebut terdapat empat pilihan jawaban, yaitu sangat setuju (SS), setuju (S), tidak setuju (TS), dan sangat tidaksetuju (TST).Angket yang diberikan berupa angket tertutup kepada 35 siswa. Pengolahan dan analisis data angket dilakukan melalui pembuatan tabulasi data dan menentukan presentase jawaban siswa.

Tabel 1.

Presentase Angket Minat Belajar

\begin{tabular}{|c|l|c|c|c|c|}
\hline No & \multicolumn{1}{|c|}{ Pernyataan } & \multicolumn{1}{|c|}{ Respon } \\
\hline A & $\begin{array}{l}\text { Indikator: Percaya diri dalam menggunakan } \\
\text { matematika }\end{array}$ & SS & TS & STS \\
\hline 1 & $\begin{array}{l}\text { Saya senang belajar matematika yang disampaikan } \\
\text { Guru dengan menggunakan media ICT berbasis for } \\
\text { VBA Ecxel (+) }\end{array}$ & 91.43 & 8.57 & 0.00 & 0.00 \\
\hline 2 & $\begin{array}{l}\text { Saya tidak memahami materi matematika dengan } \\
\text { jelas yang disampaikan Guru menggunakan media } \\
\text { ICT berbasis for VBA Ecxel (-) }\end{array}$ & 2.86 & 5.71 & 54.29 & 37.14 \\
\hline B & $\begin{array}{l}\text { Indikator: Flekibel dalam melakukan kerja } \\
\text { matematika }\end{array}$ & SS & S & TS & STS \\
\hline 3 & $\begin{array}{l}\text { Saya merasa rugi ketika ada materi matematika yang } \\
\text { terlewati (+) }\end{array}$ & 37.14 & 37.14 & 8.57 & 17.14 \\
\hline 4 & $\begin{array}{l}\text { Saya merasa waktu untuk belajar matematika dikelas } \\
\text { terlalu banyak (-) }\end{array}$ & 2.86 & 5.71 & 57.14 & 34.29 \\
\hline 5 & $\begin{array}{l}\text { Saya tidak senang ketika Guru menerangkan } \\
\text { matematika menggunakan media ICT berbasis for } \\
\text { VBA Ecxel secara tergesa-gesa (+) }\end{array}$ & 22.86 & 14.29 & 45.71 & 17.14 \\
\hline 6 & $\begin{array}{l}\text { Saya datang terlambat pada pembelajaran matematika } \\
(-)\end{array}$ & 0.00 & 2.86 & 71.43 & 25.71 \\
\hline C & $\begin{array}{l}\text { Indikator: Kerelaan meninggalkan kewajiban atau } \\
\text { tugas lain }\end{array}$ & SS & S & TS & STS \\
\hline 7 & $\begin{array}{l}\text { Saya belajar matematika karena kurikulum di Sekolah } \\
\text { mewajibkan (+) }\end{array}$ & 48.57 & 48.57 & 0.00 & 2.86 \\
\hline 8 & Saya menghindar belajar matematika karena banyak & 0.00 & 0.00 & 71.43 & 28.57 \\
\hline
\end{tabular}




\begin{tabular}{|c|c|c|c|c|c|}
\hline & PR (-) & & & & \\
\hline 9 & $\begin{array}{l}\text { Saya lebih mengutamakan pelajaran matematika dari } \\
\text { pada pelajaran lain }(+)\end{array}$ & 20.00 & 17.14 & 51.43 & 11.43 \\
\hline 10 & $\begin{array}{l}\text { Saya bosan belajar matematika menggunakan media } \\
\text { ICT berbasis for VBA Ecxel (-) }\end{array}$ & 0.00 & 5.71 & 60.00 & 34.29 \\
\hline D & 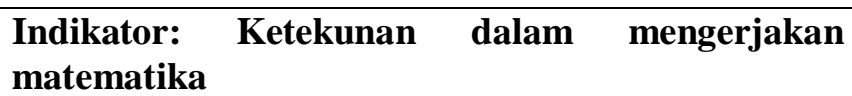 & SS & $\mathbf{S}$ & TS & STS \\
\hline 11 & $\begin{array}{l}\text { Saya mencatat penjelasan matematika yang } \\
\text { disampaikan Guru yang menggunakan media } \\
\text { berbasis for VBA Ecxel }(+)\end{array}$ & 14.29 & 85.71 & 0.00 & 0.00 \\
\hline 12 & $\begin{array}{l}\text { Saya kurang memperhatikan ketika teman bertanya } \\
\text { matematika (-) }\end{array}$ & 0.00 & 28.57 & 51.43 & 20.00 \\
\hline 13 & $\begin{array}{l}\text { Saya senang berpartisipasi dalam diskusi matematika } \\
\text { di Kelas }(+)\end{array}$ & 57.14 & 42.86 & 0.00 & 0.00 \\
\hline 14 & Saya merasa gelisah saat belajar matematika (-) & 0.00 & 0.00 & 71.43 & 28.57 \\
\hline $\mathbf{E}$ & Indikator: Dapat mempertahankan pendapat & SS & $\mathbf{S}$ & TS & STS \\
\hline 15 & $\begin{array}{l}\text { Saya berusaha keras mencari solusi masalah } \\
\text { matematika yang sulit }(+)\end{array}$ & 48.57 & 42.86 & 8.57 & 0.00 \\
\hline 16 & Saya menolak pendapat teman ketika berdiskusi (-) & 2.86 & 0.00 & 65.71 & 31.43 \\
\hline 17 & $\begin{array}{l}\text { Belajar matematika mandiri membuat saya } \\
\text { memahami matematika lebih baik }(+)\end{array}$ & 71.43 & 25.71 & 2.86 & 0.00 \\
\hline $\mathbf{F}$ & $\begin{array}{l}\text { Indikator: Gigih dan ulet dalam mengerjakan } \\
\text { tugas-tugas matematika }\end{array}$ & SS & $\mathbf{S}$ & TS & STS \\
\hline 18 & $\begin{array}{l}\text { Saya bertahan menyelesaikan soal matematika yang } \\
\text { tuntas }(+)\end{array}$ & 42.86 & 42.86 & 14.29 & 0.00 \\
\hline 19 & $\begin{array}{l}\text { Saya menolak ketika diskusi masalah matematika } \\
\text { diperpanjang (-) }\end{array}$ & 0.00 & 11.43 & 60.00 & 28.57 \\
\hline 20 & $\begin{array}{l}\text { Saya berhenti bertanya meski belum mengerti } \\
\text { matematika (-) }\end{array}$ & 8.57 & 5.71 & 37.14 & 48.57 \\
\hline
\end{tabular}

Berdasarkan hasil di atas akan dibahas mengenai pencapaian penggunaan media ICT berbasis for VBA Ecxel terhadap motivasi belajar siswa SD. Dalam pernyataan diatas ada 5 pernyataan dan 4 indikatoryang berkaitan dengan media ICT berbasis for VBA Ecxel yaitu pada pernyataan nomor 1, 2, 5, 10, dan 11. Pada indikator pertama yaitu Percaya diri dalam menggunakan matematika yang terdapat pada pernyataan nomor 1dan 2 dimana pernyataan no 1 bernilai positif, siswa paling banyak memberikan respon sangat setuju dengan total persentase sebesar $100 \%$. Pernyataan itu "Saya senang belajar matematika yang disampaikan Guru dengan menggunakan media ICT berbasis for VBA Ecxel" jadi dapat disimpulkan bahwa siswa senang belajar matematika dengan menggunakan media ICT berbasis for VBA Ecxel (Sangat Baik).

Pada pernyataan nomor 2 yang bernilai negatif, siswa paling banyak memberikan respon tidak setujudansangattdaksetuju dengan total persentase sebesar $91.43 \%$. Pernyataan itu "Saya tidak 
ANALISIS MOTIVASI BELAJAR SISWA SD ALBAROKAH 448 BANDUNG DENGAN MENGGUNAKAN MEDIA

ICT BERBASIS FOR VBA EXCEL PADA MATERI GARIS BILANGAN, Siti Romlah, Nurlela Nugraha, Siti Nurjanah,

Wahyu Setiawan

memahami materi matematika dengan jelas yang disampaikan Guru menggunakan media ICT berbasis for VBA Ecxel" jadi dapat disimpulkan bahwa siswa memahami materi matematika dengan jelas yang disampaikan Guru dengan menggunakan media ICT berbasis for VBA Ecxel (Sangat Baik).

Pada indikator kedua yaitu Flekibel dalam melakukan kerja matematika yang terdapatp ada pernyataan nomor 5 yang bernilai positif, siswa paling banyak memberikan respon tidak setujudansangattidaksetuju dengan total persentase sebesar $62.85 \%$. Pernyataan itu "Saya tidak senang ketika Guru menerangkan matematika menggunakan media ICT berbasis for VBA Ecxel secara tergesa-gesa" jadi dapat disimpulkan bahwa siswa tidak senang ketika Guru menerangkan matematika menggunakan media ICT berbasis for VBA Ecxel secara tergesa-gesa(Baik).

Pada indicator ketigayaituKerelaan meninggalkan kewajiban atau tugas lain yang terdapatpada pernyataan nomor 10 yang bernilai negatif, siswa paling banyak memberikan respon tidak setuju dansangattidaksetujudengan total persentase sebesar 94.29 \%. Pernyataan itu "Saya bosan belajar matematika menggunakan media ICT berbasis for VBA Ecxel” jadi dapat disimpulkan bahwa siswa tidak merasa bosan belajar matematika dengan menggunakan media ICT berbasis for VBA Ecxel (Sangat baik).

Pada indikator keempat yaitu Ketekunan dalam mengerjakan matematika yang terdapatpadapernyataan nomor 11 yang bernilai positif, siswa paling banyak memberikan respon setuju dengan total persentase sebesar $100 \%$. Pernyataan itu "Saya mencatat penjelasan matematika yang disampaikan Guru yang menggunakan media ICT berbasis for VBA Ecxel" jadi dapat disimpulkan bahwa siswa mencatat penjelasan matematika yang disampaikan Guru yang menggunakan media ICT berbasis for VBA Ecxel (Sangat baik).

Berdasarkan penjelasan dari kelima pernyataan dan keempat indikator di atas dapat disimpulkan bahwa penggunaan media ICT berbasis for VBA Ecxel dalam pembelajaran matematika dapat mempengaruhi motivasi belajar siswa lebih meningkat. Hal ini pun bersesuaian dengan penelitian yang telah dilakukan oleh Bernard (2018) bahwa penerapan pembelajaran matematika menggunakan media ICT berbasis VBA Excel dapat membantu siswa menyelesaikan permasalahan matematika dengan mudah dan menumbuhkan motivasi belajar matematik siswa. Juga menurut hasil penelitian Mahmud (2007) motivasi dan hasil belajar siswa Kelas V SDN Model Terpadu Madani yang mengikuti pembelajaran dengan media berbasis TIK yaitu ICT lebih baik jika dibandingkan dengan pembelajran biasa. Dari hasil penelitian Rizki (2015) bahan ajar berbasis ICT ini sangat baik untuk digunakan dalam proses pembelajaran. Lebih lanjut dari hasil analisis data dapat disimpulkan bahwa ada pengaruh yang sangat signifikan pada motivasi belajar siswa dan penggunaan bahan ajar berbasis ICT terhadap hasil belajar.Senjayawati (2019) juga mengatakan pembelajaran berbasis ICT VBa Excel lebih menarik dan menambah motivasi siswa dalam belajar matematika dan meningkatkan hasil belajar siswa. 


\section{KESIMPULAN}

Berdasarkan hasildan pembahasan yang telah disajikan, maka dapat disimpulkan bahwa dari rata-rata skor keseluruhan soal dari semua indicator, siswa termasuk ke dalam kriteria sangat baik yaitu $88,21 \%$.

\section{DAFTAR PUSTAKA}

Arikunto,S. (2008). Prosedur Penelitian: Suatu Pendekatan Praktek. Jakarta: PT.Rineka Cipta

Bernard, Minarti \& Hutajulu. (2018).Contructing Student's mathematical Understanding Skills and Self Confindece: Math Game with Visual basic Application for Miscrosoft Excel in Learning Phytagoras at Junior High School. International Journal of Engineering \& Technology, $7(3.2) .732-736$.

Bernard, M., \& Senjayawati, E. (2019). Developing the Students' Ability in Understanding Mathematics and Self-confidence with VBA for Excel. JRAMathEdu (Journal of Research and Advances in Mathematics Education), 1(1), 45-56.

Hamdani. (2011). Strategi Belajar Mengajar. Bandung : CV Pustaka Setia.

Mahmud. (2015). Identifikasi Faktor-Faktor Yang Mempengaruhi Motivasi Belajar Mahasiswa Pada Mata Kuliah Stenografi di Program Studi Pendidikan Ekonomi Perkantoran Fakultas Ekonomi dan Bisnis Universitas Negeri Gorontalo. Aksara Jurnal Ilmu Pendidikan Nonformal Vol. 1 Nomor. 04, September 2015: 407-418

Nugraha, N., Kadarisma, G., \& Setiawan, W. (2018). Analisis Kesulitan Belajar Matematika Materi Bentuk Aljabar Pada Siswa SMP Kelas VII. Journal On Education, 01(02), 323-334.

Pebriana. (2017) Peningkatan hasil Belajar Matematika dengan Menerapkan Pendekatan Pendidikan Matematika Realistik Indonesia (PMRI) pada siswa kelas V SDN 003 Bangkinang. Jurnal Cendikia: Jurnal Pendidikan Matematika,1(1), 68-79

Rizki \& Widaniati. (2015). Efektifitas Bahan Ajar dan Media Berbasis ICT Pada Materi Persamaan dan Fungsi Kuadrat. AKSIOMA: Jurnal Progran Studi Pendidikan Matematika, 4(2)

Romlah, S., Kadarisma, G., \& Setiawan, W. (2018). Analisis Kemampuan Komunikasi Matematik Siswa Smp Mutiara 1 Bandung Pada Materi Bentuk Aljabar. Journal On Education, 01(02), $37-46$.

Sudirman. (2007). Interaksi dan Motivasi Belajar Mengajar. Jakarta: Raja Grafindo Persada. 